\title{
Commercial Bombus impatiens as reservoirs of emerging infectious diseases in central México
}

\author{
Bernardo Sachman-Ruiz • \\ Verónica Narváez-Padilla \\ Enrique Reynaud
}

Received: 8 April 2014/ Accepted: 24 February 2015/Published online: 10 March 2015

(C) The Author(s) 2015. This article is published with open access at Springerlink.com

\begin{abstract}
The rapid decline in range and relative abundance of some wild North American bumble bee species, combined with the commercialization of bumble bee colonies as agricultural pollinators, and recent evidence that bumble bees can be infected by honey bee viruses, suggest the possibility that invasive and emerging infectious diseases (EIDs) may play a substantial current and future role in the decline of
\end{abstract}

B. Sachman-Ruiz

Laboratorio de Ingeniería Genómica, Centro de Ciencias Genómicas, Universidad Nacional Autónoma de México, Avenida Universidad, 2001,

Apartado Postal 565-5-A, Cuernavaca, Mexico

B. Sachman-Ruiz

Centro Nacional de Investigación Disciplinaria en Parasitología Veterinaria, Instituto Nacional de Investigaciones Forestales Agrícolas y Pecuarias (INIFAP), Carr. Fed. Cuernavaca-Cuautla No. 8534, CP 62550 Jiutepec, Morelos, Mexico

\section{Narváez-Padilla}

Facultad de Ciencias, Universidad Autónoma del Estado de Morelos, Av. Universidad 1001, Col. Chamilpa, 62209 Cuernavaca, Morelos, Mexico

E. Reynaud $(\bowtie)$

Departamento de Genética del Desarrollo y Fisiología Molecular, Instituto de Biotecnología, Universidad Nacional Autónoma de México, Avenida Universidad, 2001, Apartado Postal 510-3, 62210 Cuernavaca, Mexico e-mail: enrique@ibt.unam.mx wild bumble bee populations. Pollination in North American greenhouses is primarily mediated by industrially produced Bombus impatiens colonies. The use of $B$. impatiens is preferred in greenhouses because it is a native species of East North America and they are very efficient pollinators. However, $B$. impatiens is also host of various viruses that have been associated with colony collapse disorder in honey bees, as well as hosts to a number of bumble beespecific pathogens and parasites. In this study, we used qPCR to screen adult worker bumble bees collected from 120 different greenhouses in central Mexico. Fifty-four locations were positive for one or more pathogens $(45 \%)$. The most frequently detected pathogen was Apicystis bombi, which was present in 32 colonies. Of these $32 \mathrm{~A}$. bombi positive colonies, 15 were co-infected with at least one other pathogen or parasite, such as Locustacarus buchneri, Nosema bombi, or the viral pathogens ABPV, CBPV, DWV, IAPV and KBV. Routine use of this type of screening technology together with policy changes to restrict pathogen infested commercial bumble bees should help improve the selection of healthy commercial colonies of $B$. impatiens and could lead to a higher efficiency in greenhouse pollination thus providing better environmental conservation of natural Bombus spp. by preventing spillover of EIDs.

Keywords Colony collapse disorder - Bumble bee diagnosis $\cdot$ Emerging infectious diseases $\cdot$ Pathogen spillover 


\section{Introduction}

The importance of $B$. impatiens as a commercial pollinator

Traditionally, pollination was considered a gratuitous environmental service. A large percentage of the global food supply is naturally pollinated by wild insects, birds and mammals (Ollerton et al. 2011). The annual global economic impact of this natural service has been estimated in 200 trillion dollars (Gallai et al. 2009). The decimation of populations of natural pollinators, the increase in global food demand and the introduction of noxious species, such as the Africanized honey bee, have led to the use of commercially available pollinators, such as Bombus impatiens and B. terrestris whose demand has been growing steadily (Stubbs and Drummond 2001; Velthius and Van Doorn 2006).

Bumble bees (Bombus spp., Hymenoptera, Apidae) are naturally distributed throughout North America, and they are ecologically important native plant pollinators (Kearns and Thomson 2001). At the end of the last century, private companies began to massively produce and distribute $B$. terrestris and $B$. impatiens colonies for commercial pollination of Solanum lycopersicum (i.e., tomato) (Whittington and Winston 2004), Capsicum annuum (i.e., bell pepper) (Shipp et al. 1994) and Vaccinium angustifolium (i.e., cranberries) (Stubbs and Drummond 2001), among many other commercial species. In Europe alone, the annual market value of $B$. terrestris is estimated to be 55 million Euros (Meeus et al. 2010a). In North America 55,000 B. impatiens colonies were sold in 2005 representing a market of about five million US dollars (Velthius and Van Doorn 2006), and the demand seems to be growing steadily.

Global epidemiological status of $B$. impatiens pathogens

Some of the pathogens that infect honey bees and bumble bees such as Nosema cerenae, Apicystis bombi and DWV have been recently catalogued as emerging infectious diseases (EIDs) (Arbetman et al. 2012; Maharramov et al. 2013; Fürst et al. 2014). The intensive production and global dispersal of commercial B. impatiens can transmit hymenopteran diseases to naturally occurring honey bee and bumble bee populations (Whittington and Winston 2004; Singh et al. 2010). Previous studies have demonstrated that wild bumble bees collected near greenhouses that have commercial B. impatiens colonies are more likely to be infected than naturally occurring colonies by Crithidia bombi, a protozoan pathogen that infest the bumble bee gut, the fungus Nosema bombi that causes a systemic infection, and the mite Locustacarus buchneri (Colla et al. 2006; Morkeski and Averil 2010). N. bombi infects a wide range of bumble bee species (Tay et al. 2005) and has likely contributed to the recent collapse of commercial populations of Bombus occidentalis in North America. However it is not clear if the infection is the cause of the decline or a consequence of a reduction of genetic variation caused by the decline (Brown 2011). C. bombi infection lowers the reproductive yield of bumble bee colonies by up to $40 \%$ (Brown et al. 2003) and reduces the survival of individual workers by up to $50 \%$ when food is scarce (Brown et al. 2000). In addition, a single individual may be simultaneously infected with a variety of EIDs (Meeus et al. 2010a). Therefore, there is a possibility that these individuals could simultaneously transmit viral, protozoan and fungal pathogens (Celle et al. 2008).

The recent development of molecular diagnostic techniques has allowed the identification of honey bee viruses that reduce production yield and have the potential to collapse honey bee hives. The most common and aggressive examples are the acute paralysis bee virus (APBV), the chronic bee paralysis virus (CBPV), the deforming wing virus (DWV), the Israel acute paralysis virus (IAPV) and the Kashmir bee virus $(\mathrm{KBV})$. These viruses can infect honey bee colonies for years without producing apparent disease and then suddenly kill the entire colony for unknown reasons (Blanchard et al. 2008). CBPV was first isolated from infected honey bees in 1963 (Bailey et al. 1963), and the dispersal of this virus has been extensive in recent years (Berényi et al. 2007). Phylogenetic analysis of the IAPV genome indicated that IAPV clusters together with KBV and ABPV (Maori et al. 2007). Metagenomic studies of honey bee colonies with Colony Collapse Disorder (CCD) have demonstrated that these three viral strains were found simultaneously in collapsed colonies (Cox-Foster et al. 2007). It has been shown that these viruses can also infect $B$. impatiens colonies, this work and Meeus et al. (2010a, b). 
Commercial B. impatiens in Mexico, use and regulatory framework

In Mexico, there are two major bumble bee producers which have a presence in over 50 countries. Tens of thousands of colonies are produced annually and used in the domestic market. The number of bumble bees colonies imported into Mexico varies each year (from 7000 in 2008 to 24,000 in 2007), and a Federal Law of Animal Health (http://www.senasica.gob.mx/) regulates the importation of agricultural products into Mexico, including requirements for three species of bumble bees: $B$. impatiens, B. occidentalis, and $B$. ephippiatus, even though $B$ occidentalis is no longer commercially available. The restrictions require that shipments of bumble bees imported into Mexico must be accompanied with official health certificates stating that the bumble bees are free of infections, including those caused by Nosema spp., Varroa spp., and fungal pathogens (http://www.senasica.gob.mx/), however, there are no available data quantifying this regulatory activity. In fact, Mexican regulations about bumble bee pathogens are in general very vague. For example, there is no regulation or restriction for outdoor use of commercial bumble bees. However, to our knowledge, it is not commercially viable to use them for open crop field pollination, therefore, most commercial bumble bee colonies are only used in greenhouses. Interestingly there are no Mexican regulations regarding any hymenopteran viruses. (http://www.biodiversidad. gob.mx/pais/pdf/Estrategia_Invasoras_Mex.pdf).

\section{Identification of pathogens in B. impatiens}

Protozoan, acarid and fungal parasites of B. impatiens are traditionally identified by microscopic observation of gut and tracheal preparations (Goka et al. 2001; Colla et al. 2006; Plischuk and Lange 2009; Al-Abbadi et al. 2010). These techniques have a number of disadvantages: many parasites are difficult to detect visually when they present at a low titers, there are few qualified technicians due to the requirement for specific training, and it is difficult to discriminate between closely related parasite species, also others are impossible to culture in vitro so there are no reference strains. In addition, these techniques are time consuming, making it difficult to efficiently screen large numbers of samples. For all these reasons molecular methods are probably the best approach to monitor EIDs.
The genomes of the most damaging honey bee viruses, including KBV, IAPV, APBV, DWV and CBPV have been sequenced in the last decade (Govan et al. 2000; de Miranda et al. 2004; Lanzi et al. 2006; Celle et al. 2008). The availability of these sequences has facilitated the development of molecular diagnostics for these viruses that can be used in asymptomatic organisms (Yue and Genersch 2005). There is a large amount of evidence that suggest that all these viruses and pathogens are harmful or have the potential to be harmful to bumble bees. However, the causes for the decline of wild bumble bee populations are difficult to elucidate as reviewed by Brown in 2011 (Brown 2011). These methods have yet to be extensively applied to the diagnosis of B. impatiens and other commercial hymenopterans. Epidemiological surveys of these species are necessary due to their ecological and economic importance. Meeus et al. (2011) suggest that the development of molecular screening protocols might immediately mitigate these threats. In this study, we developed five de novo molecular diagnostic tests for eukaryotic pathogens. We also used quantitative PCR to determine the prevalence, the colony coinfection rate and the infection colony load of five viruses in B. impatiens colonies obtained in the Mexican state of Queretaro. Finally, we discuss the potential ecological impacts of commercial B. impatiens populations on communities of indigenous bees and bumble bees and outline the diagnostic and certification tools that should be implemented to minimize ecological risk and maximize crop productivity.

\section{Materials and methods}

\section{Field sampling of B. impatiens}

Bombus impatiens samples were donated by anonymous commercial greenhouses that use commercial bumble bee colonies for pollination produced in Mexico. The authors have no affiliations with the commercial greenhouses. All samples were graciously donated by producers on the condition of anonymity. The bumble bee producers do not make any claim about the health of the hives. However they do guarantee a minimum amount of workers ( 80 per large hive).To avoid any site contamination, the samples were obtained from newly opened commercial 
colonies. The trademark of the bumble bees was anonymized so that the technician would be blinded to the sample source. Batches of $10 \mathrm{~B}$. impatiens individuals were collected from each colony. We assume that this population represents the overall health status of the colony. In total, 120 batches from 120 different greenhouses were analyzed. To avoid the possible contamination of the samples with native Bombus ephippiatus, all individuals were classified to ensure that they had a pale tergum 1 and a completely black tergum 2 (Duennes et al. 2012a). The animals were kept alive in flasks with a swab of cotton soaked in sucrose prior to processing in the laboratory.

\section{Purification of RNA from B. impatiens}

Bombus impatiens individuals were anesthetized with $\mathrm{CO} 2$ before processing. The abdomens from each location were cut in half, homogenized and pooled. The total RNA from these pools of ten individuals was extracted using the Trizol $^{\circledR}$ reagent (Invitrogen, Carlsbad, CA, USA) according to manufacturer instructions. RNA was quantified using a Nanodrop 3000 spectrophotometer, and the quality of the RNA was determined by electrophoresis in a MOPS/formaldehyde $1.5 \%$ agarose gel.

cDNA synthesis

One microgram of total RNA from each RNA pool was used for cDNA synthesis. The reaction was performed in a volume of $20 \mu$ that contained the following: $1 \mu \mathrm{g}$ of total RNA, $1 \mathrm{X}$ reverse transcriptase reaction buffer and $300 \mathrm{ng}$ of random hexamers. The reaction was incubated at $65^{\circ} \mathrm{C}$ for $5 \mathrm{~min}$ and transferred to ice. The M-MuLV reverse transcriptase (New England Biolabs) was added, and the reaction was incubated at $37^{\circ} \mathrm{C}$ for $1 \mathrm{~h}$. The enzyme was subsequently inactivated by incubating the reaction at $65^{\circ} \mathrm{C}$ for $10 \mathrm{~min}$. For qPCR, the cDNA was diluted $1: 20$, and $1 \mu \mathrm{l}$ of the diluted cDNA was used as substrate.

Primer and probe design

All available sequences for each pathogen were obtained from Genbank. The Basic Local Alignment Sequence Tool (BLAST) was used to compare the pathogen sequences to sequences from close taxonomic groups. Variable regions were identified, as these regions are the most informative and the most likely to be unique for each organism. The variable regions were again subjected to BLAST to identify sequences that retrieved only the pathogen of interest and not pathogens from closely related taxa. These sequences were then analyzed using PrimerExpress 5.0 software, and the primer and TaqMan ${ }^{\circledR}$ probe set that presented the best physicochemical scores (i.e., lack of hairpin formation, duplex formation, higher stability and Tm) for each pathogen were synthesized (Applied Biosystems, USA). The sequences for all primers and $\mathrm{TaqMan}^{\circledR}$ probes are presented in Table 1 .

Positive control design

The informative sequences that were identified during primer design were synthesized at GenScript (GenScript, Piscataway, NJ, USA) and cloned into pUC57 flanked by EcoRI and HindIII sites. Serial dilutions of these clones $\left(10^{-2}-10^{-6} \mathrm{ng}\right.$ of plasmid) were performed to establish a reference curve. Target, primer and probe sequences are presented in Table 1.

\section{Quantitative PCR}

qPCR reactions were performed using the universal TaqMan $^{\circledR}$ PCR master mix (Applied Biosystems) according to manufacturer instructions. However, the reactions were scaled down to a volume of $14 \mu \mathrm{l}$. The TaqMan ${ }^{\circledR}$ probe was used at a final concentration of 25 $\mathrm{nM}$, and $1 \mu \mathrm{l}$ of a 1:20 dilution of the cDNA reaction was used for the detection of each pathogen. Alternatively, reactions were performed using the $\mathrm{SYBR}^{\circledR}$ Green Universal PCR Master Mix. The following PCR conditions were used: $95{ }^{\circ} \mathrm{C}$ for $5 \mathrm{~min}, 40$ cycles of $95{ }^{\circ} \mathrm{C}$ for $15 \mathrm{~s}$, and $59{ }^{\circ} \mathrm{C}$ for $1 \mathrm{~min}$. In all cases, the specificity of the reactions was confirmed using polyacrylamide gel electrophoresis (PAGE). Positive controls (i.e., synthetic DNA) and negative controls (i.e., lack of target sequences) were included in all experiments.

\section{Statistical analysis}

Standard deviations, linear regressions and correlation indexes were calculated using Microsoft Excel. 
Table 1 Pathogen sequences used in this work

\begin{tabular}{|c|c|c|c|c|c|}
\hline $\begin{array}{l}\text { Eukaryota } \\
\text {-Quencher }\end{array}$ & Sequence & $\begin{array}{l}\mathrm{Tm}^{\circ} \mathrm{C} \\
\text { Pri/Pro }\end{array}$ & $\begin{array}{l}\text { Position bp } \\
\text { length }\end{array}$ & Gene & $\begin{array}{l}\text { Genbank } \\
\text { Acces No. }\end{array}$ \\
\hline $\begin{array}{l}\text { A. bombi } \\
\text { FAM }\end{array}$ & $\begin{array}{l}\text { 5'GAAACGGCTACCACATCTAAGGAAGGCAGCAGGCGCGCAAATTACCCAATCC } \\
\text { TGACATAGGGAGGTAGTGACAAGAAA3' }\end{array}$ & $59 / 70$ & $341-418 / 77$ & Rrs & FN546182.1 \\
\hline $\begin{array}{l}\text { C. bombi } \\
\text { FAM }\end{array}$ & $\begin{array}{l}\text { 5'CTCTCCTTCTCGTCTCTCTTCTTCTCTTCCCTTCTCTCTCCCCC } \\
\text { TGCATGCACATACACGTGTGT3' }\end{array}$ & $59 / 69$ & $274-338 / 64$ & Rrs & GU321148.1 \\
\hline $\begin{array}{l}\text { L.buchner } \\
\text { VIC }\end{array}$ & $\begin{array}{l}\text { 5'CCATTATCAAGAACCCCATTCCAAAGAAAGTCAATAGACATAACCA } \\
\text { TTCTCTCAATTCACCTAGCAGGAA3' }\end{array}$ & $58 / 69$ & $107-176 / 70$ & Cit-Oxi & AB052703.1 \\
\hline $\begin{array}{l}\text { N. bombi } \\
\text { FAM }\end{array}$ & $\begin{array}{l}\text { 5'TGACGGAAGAATACCACAAGGAGTGGATTGTGCGGCTTAA } \\
\text { TTTGACTCAACGCGAGGTAACTT3', }\end{array}$ & $59 / 69$ & $742-804 / 62$ & Rrs & HM142729.1 \\
\hline $\begin{array}{l}\text { S. bombi } \\
\text { FAM }\end{array}$ & $\begin{array}{l}\text { 5'CGGTTAAAAAGCTCGTAGTTGGATCTGTGCCCGGGACTTGGTCCACCT } \\
\text { TTTAGGT GCGCACTAGGCTTC3' }\end{array}$ & $59 / 68$ & $565-633 / 68$ & Rrs & AB250213.1 \\
\hline $\begin{array}{l}\text { Virus } \\
\text { Quencher }\end{array}$ & Sequence & $\begin{array}{l}\mathrm{Tm}^{\circ} \mathrm{C} \\
\text { Pri/Pro }\end{array}$ & $\begin{array}{l}\text { Position bp } \\
\text { length }\end{array}$ & Coding & $\begin{array}{l}\text { Genbank } \\
\text { Acces No. }\end{array}$ \\
\hline $\begin{array}{l}\text { ABPV } \\
\text { FAM }\end{array}$ & $\begin{array}{l}\text { 5'TGCTCGAGCTGGTAATGATGATTTCACTTTTGGATGGCTCATAG } \\
\text { GAACACCGCAAACTCAAG GAA3' }\end{array}$ & $59 / 68$ & $9166-9230 / 64$ & capside & AF150629.1 \\
\hline CBPV VIC & $\begin{array}{l}\text { 5'CATCGGCAACGGATTCATCAACGCATTCATTATCTGGC } \\
\text { TCTGTCTTCGCAAACTGCCC } 3 \text {, }\end{array}$ & $60 / 68$ & $1209-1266 / 57$ & RNApol & FJ345309.1 \\
\hline DWV FAM & $\begin{array}{l}\text { 5'CATGCATATTGGCGTGGAGATATGGAAGTTCGAGTGCAGATTAAC } \\
\text { TCGAATAAATTCCAGGTTGGTCA3' }\end{array}$ & $59 / 70$ & $2094-2161 / 67$ & polypro & HM067437.1 \\
\hline IAPV VIC & $\begin{array}{l}\text { 5'GTGGAAACTCCAAATAGGATCGATACCCCCATGGCTCAGGATACT } \\
\text { TCATCGGCTAGGAGCATGG3' }\end{array}$ & $58 / 70$ & $595-658 / 63$ & RNApol & EU436450.1 \\
\hline KBV FAM & $\begin{array}{l}\text { 5'GCATCGAGCGCATTCCAGTGCTAGGTGAAATTGCAAAGC } \\
\text { CAGTAACCGCTGCAGTTAAATGG3' }\end{array}$ & $60 / 69$ & $6735-6798 / 1$ & RNApol & AY275710.1 \\
\hline
\end{tabular}

Primer sequences are shown in gray, parasite genomic sequences are shown in black and the probe sequences are underlined. The Tm for each Primers (Pri) and Probes (Pro) $\mathrm{Tm}_{\mathrm{s}}$ are included, together with genomic coordinates and Genbank accession numbers are also provided

\section{Results and discussion}

The objective of this work was to study the prevalence of ten common pathogens that infect bumble bees in the central Mexican state of Queretaro, where commercial bumble bees are used extensively for greenhouse production, particularly for production of the tomato S. lycopersicum. We screened adult worker bumble bees from 120 different greenhouses. To make the screen economically feasible, we pooled ten individuals from each location (colony) into a single sample. We can assume that each pool represents the infection status of a particular bumble bee colony at the moment the sample was taken (when the colony boxes were opened for first time in the greenhouse). The pooling strategy makes sense because it has been demonstrated that bumble bee workers can be infected by the exposure to fecal matter of bumble bees or by pollen that is contaminated by these parasites and that these infections become systemic in the colony, it has also been observed that the infection rate tends to be greater after shipment (Graystock et al. 2013). Of the 120 locations, 54 were positive for one or more pathogens $(45 \%)$.

We developed a spectrum of pathogen probes for the detection of the acaroid Locustacarus buchneri, the nematode Sphaerularia bombi, the protozoans
Apicistis bombi and Crithidia bombi, the fungus Nosema bombi, together with the viral pathogens ABPV, CBPV, DWV, IAPV and KBV. The most frequently found pathogen was $A$. bombi, which was present in 32 locations. Of the 32 samples infected with $A$. bombi, 15 were co-infected with another pathogen: four samples were co-infected with the parasite L. buchneri, one sample was co-infected with N. bombi, three samples were co-infected with ABPV, three samples were co-infected with CBPV, one sample was co-infected with DWV, one sample was co-infected with IAPV, one sample was co-infected with $\mathrm{KBV}$, and a final colony sample had a triple infection with A. bombi, DWV and IAPV. Interestingly the triple-infected sample was also the sample that carried the highest infection load for the three detected pathogens. Twelve locations were infected with $C$. bombi, and two of these colony samples were co-infected with ABPV. Ten other locations had single infections: 3 ABPV infections, 5 CBPV infections, 1 DWV infection and $1 \mathrm{KBV}$ infection (Table 2; Fig. 1). All reactions were performed in triplicate using TaqMan $^{\circledR}$ and SYBR ${ }^{\circledR}$ Green. The specificity of the TaqMan $^{\circledR}$ and SYBR ${ }^{\circledR}$ Green results was always confirmed using PAGE, which only detected a single band of the expected molecular weight (Fig. 2). In this sample population, no false positives were detected. 
Table 2 Positive samples positive for one or more pathogens

\begin{tabular}{|c|c|c|c|c|c|c|c|c|c|c|c|}
\hline Pathogen & A. bombi & C. bombi & L. buchneri & N. bombi & S. bombi & ABPV & CBPV & DWV & IAPV & KBV & DWV/IAPV \\
\hline A. bombi & 17 & - & 4 & 1 & - & 3 & 3 & 1 & 1 & 1 & 1 \\
\hline C. bombi & & 10 & - & - & - & 2 & - & - & - & - & - \\
\hline L. buchneri & & & - & - & - & - & - & - & - & - & - \\
\hline N. bombi & & & & - & - & - & - & - & - & - & - \\
\hline S. bombi & & & & & - & - & - & - & - & - & - \\
\hline ABPV & & & & & & 3 & - & - & - & - & - \\
\hline CBPV & & & & & & & 5 & - & - & - & - \\
\hline DWV & & & & & & & & 1 & - & - & - \\
\hline IAPV & & & & & & & & & 1 & - & - \\
\hline KBV & & & & & & & & & & 1 & - \\
\hline
\end{tabular}

$45 \%$ samples of RNA were positive for at least one of the analyzed pathogens

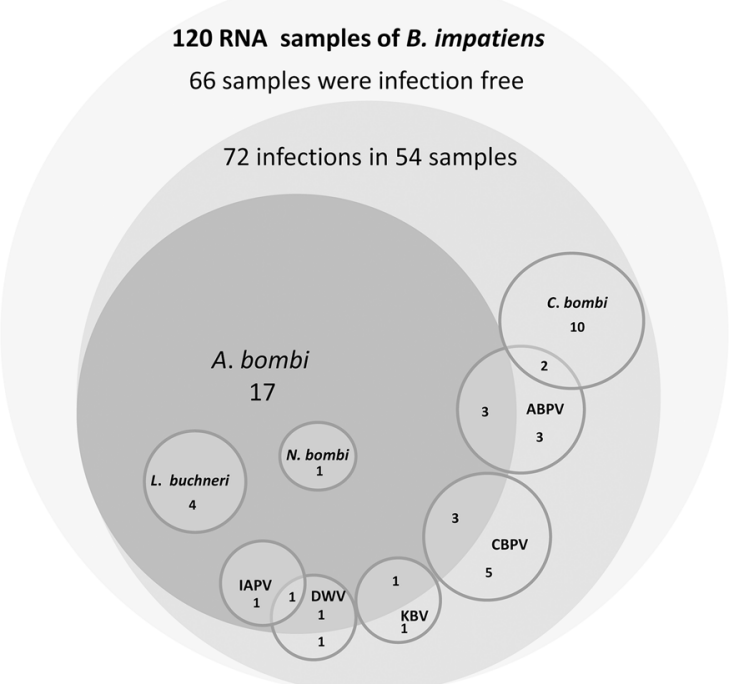

Fig. 1 Proportional diagram of representing the infections and co-infections detected of in 120 RNA samples. Circles represent the population size and the relationships of between samples presenting with one or more infections

Our results demonstrate that we can routinely, quantitatively and reliably detect as little as $10^{-5} \mathrm{ng}$ of synthetic DNA, which represents approximately 35000 copies of each target, using conventional qPCR technologies (Table 3). At lower concentrations, the target can be reliably detected but not reliably quantified (Yukl et al. 2013). Synthetic DNA constructs served dual purposes, acting as both positive controls and quantified standards that facilitated the creation of standard curves to define the lower limit of detection. Our probes have high sensitivity and specificity, as evidenced by the absence of false positives. We also included negative controls in which we used cDNA from the unrelated hymenoptera Scaptotrigona mexicana and the dipteran Drosophila melanogaster. Both of these controls were negative for all of the tested pathogens (data not shown). It is important to note that viruses cannot be directly visualized by conventional microscopy, therefore electron microscopy, molecular or immunological techniques are the only option to detect these pathogens, for this reason, we think that the best available technique to detect a wide range of pathogens and parasites are probably methodologies involving molecular biology. The high sensitivity and specificity of the test was reproduced for all pathogens tested. Because the viral pathogens tested in this study also infect the honey bee Apis mellifera, we generated a powerful tool that will be helpful for screening the health and the incidence of EIDs of honey bee and bumble bee colonies. Our results indicate that $45 \%$ of commercial B. impatiens populations are infected with at least one pathogen. Importantly, $40 \%$ of the detected infections were caused by viruses that are associated with colony collapse disorder (Table 4).

In most cases, $A$. bombi was found at very low titer (Table 3). This result is inconsistent with previous studies in which A. bombi was not found in commercial bumble bees (Colla et al. 2006). However, the authors of that study suggested that the absence of this parasite in their samples may be due to the greenhouse 
Fig. 2 Standard curves for each pathogen target. Standard deviations and linear regressions are shown $\left(\mathrm{n} \geq>=3\right.$ ). SYBR ${ }^{\circledR}$ Green amplification specificity for the pathogen targets is shown presented on in the panels on to the left of each amplification curve
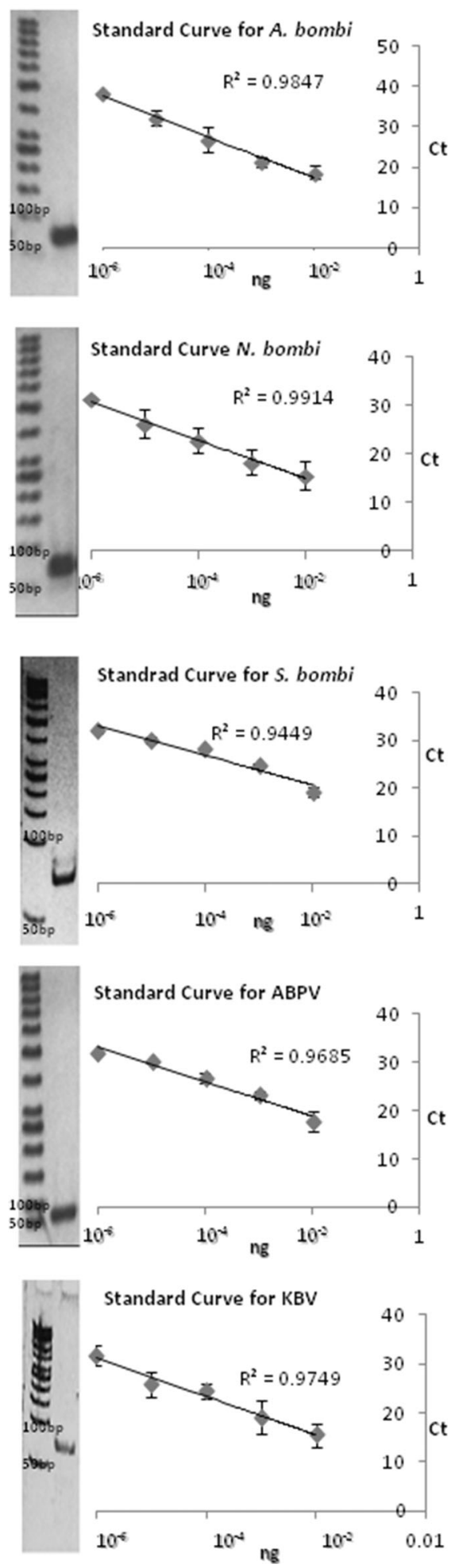

Standard Curve for C. bombi
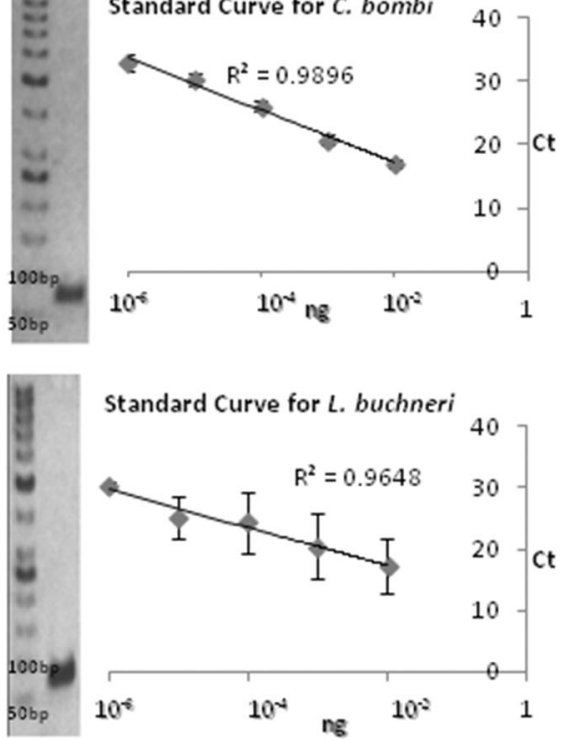

Standard Curve for L. buchneri

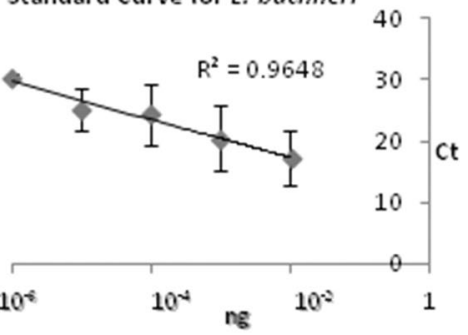

Standard Curve for IAPV
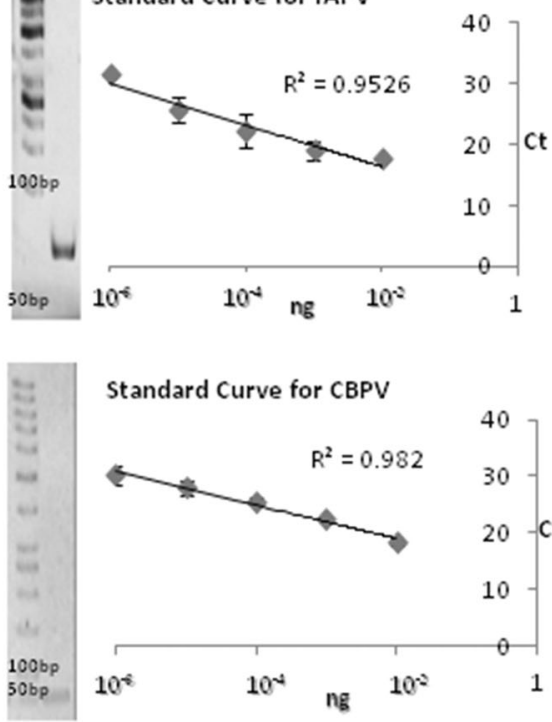

Standard Curve for CBPV
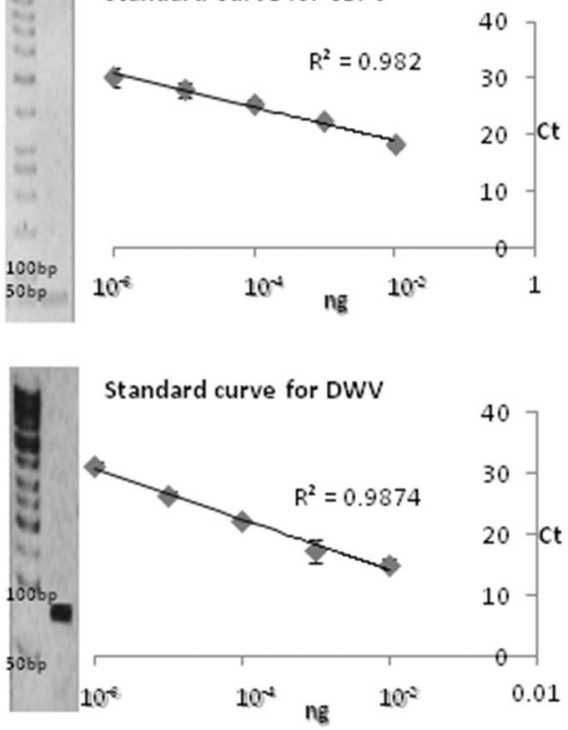
Table 3 Ranges for the number of molecules detected of for each pathogen

Number of parasite molecules detected per sample (Taqman assay)

\begin{tabular}{|c|c|c|c|c|c|c|c|c|}
\hline A. bombi & C. bombi & L. buchneri & N. bombi & ABPV & CBPV & DWV & IABPV & $\mathrm{KBV}$ \\
\hline $\begin{array}{r}6.3 \times 10^{5} \text { to } \\
2.4 \times 10^{12}\end{array}$ & $\begin{array}{l}9.7 \times 10^{7} \text { to } \\
2.7 \times 10^{10}\end{array}$ & $\begin{array}{l}\geq 2.5 \times 10^{3} * \\
\quad \text { to } \\
\quad 4.3 \times 10^{3}\end{array}$ & $1.2 \times 10^{6}$ & $\begin{array}{l}2.0 \times 10^{5} \\
\text { to } \\
8.0 \times 10^{5}\end{array}$ & $\begin{array}{l}2.0 \times 10^{3} \\
\quad \text { to } \\
7.7 \times 10^{4}\end{array}$ & $\begin{array}{l}1.4 \times 10^{4} \\
\text { to } \\
4.6 \times 10^{5}\end{array}$ & $\begin{array}{l}3.6 \times 10^{4} \\
\quad \text { to } \\
4.7 \times 10^{5}\end{array}$ & $\begin{array}{l}1.3 \times 10^{4} \\
\text { to } \\
9.1 \times 10^{4}\end{array}$ \\
\hline
\end{tabular}

* The low titer in of these samples does not allow the assay to be quantitative because it is below the detection limit of the qPCR. However, the parasite is clearly present in these samples, because no signal was detected in the negative controls, the signal was very robust in the positive controls, a single product was observed in via PAGE and results were reproducible in field samples

bumble bees restrictive diet, which leads to a diminished amount of fat tissue. In addition, the sensitivity of molecular techniques is several orders of magnitude higher than that of microscopic techniques, which are not sensitive enough to detect very low titers of parasites. Future studies may develop antibodies and use immunostaining techniques to identify the organs infected by $A$. bombi in commercial bumble bees, although these experiments are beyond the scope of the present work.

On the other hand, it has recently been described that $A$. bombi has travelled in commercially produced $B$. terrestris colonies and invaded new ecosystems such as Patagonia. The introduced European species $B$. ruderatus and the patagonian native $B$. dahlbomii were infection free in Patagonia previous to the introduction of $B$. terrestris and became positive for this parasite thereafter. Thus suggesting that this parasite can infect native Bombus species that are different from their original host (Arbetman et al. 2012; Maharramov et al. 2013). This evidence also indicates that $A$. bombi has recently been transferred at least once from Europe to South America (Maharramov et al. 2013). Other important examples of pathogen spillover in different parts of the world include: the dissemination of European L. buchneri by $B$. terrestris to wild Japanese bumble bee populations (Yoneda et al. 2008); the role commercial B terrestris as reservoir of the parasites C. bombi, A. bombi and $N$. bombi in Scotland (Whitehorn et al. 2013) and the high infection rate of wild bumble bees whose colonies are close to commercial greenhouses in Ontario, Canada (Otterstatter and Thomson 2008). Colonies with multiple infections have also been reported in other studies (Rutrecht and Brown 2008).

It should be noted that greenhouse bumble bees live in stressful conditions that likely increase their susceptibility to disease. It has been proposed that a combination of colony co-infection with multiple parasites and environmental stresses are the causes of the diseases that are decimating bumble bee colonies in North America (Kissinger et al. 2011; Graystock et al. 2013, 2014). It has also been suggested that the presence or introduction of $N$. bombi correlates with the decline of native North American bumble bee populations (Cameron et al. 2010). Therefore, it is most worrisome that several of these pathogens can be transferred between commercially produced bumble bees and wild bumble bees (Colla et al. 2006). Bumble bees are traded globally for commercial purposes. In Mexico, the biggest producers are Koppert (http:// www.koppert.com.mx/) and Bio-Best (http://www. biobest.be/vestigingen/0/4/). Both of these companies are present in at least 50 countries. Honey beehives are frequently rented and transported over large geographic distances. Bumble bee colonies are also transported across continents and sold annually by the hundreds of thousands (Velthius and Van Doorn 2006; Watanabe 2006; Morkeski and Averil 2010). The life cycles of these colonies involves annual colony foundation by fertilized queens. Most of these queens are unlikely to survive greenhouse agricultural cycles, but there is the potential for queens to escape. Instances of escape have already been reported in central Mexico (Pitts-Singer and James 2008) and other countries such as Japan (Goka 2010a). The transportation of thousands of individuals across continents presents an opportunity for the spread of emergent pathogens into new environments and danger to biodiversity (Colla et al. 2006; Fürst et al. 2014). For example, genetic dilution of native bumble bees has been demonstrated in Japan following the introduction of B. terrestris (Kondo et al. 2009). Additionally there are several other factors of ecological concern that may result from the introduction of alien pathogens and insect species, among these are: (1) Native pathogens may evolve a 


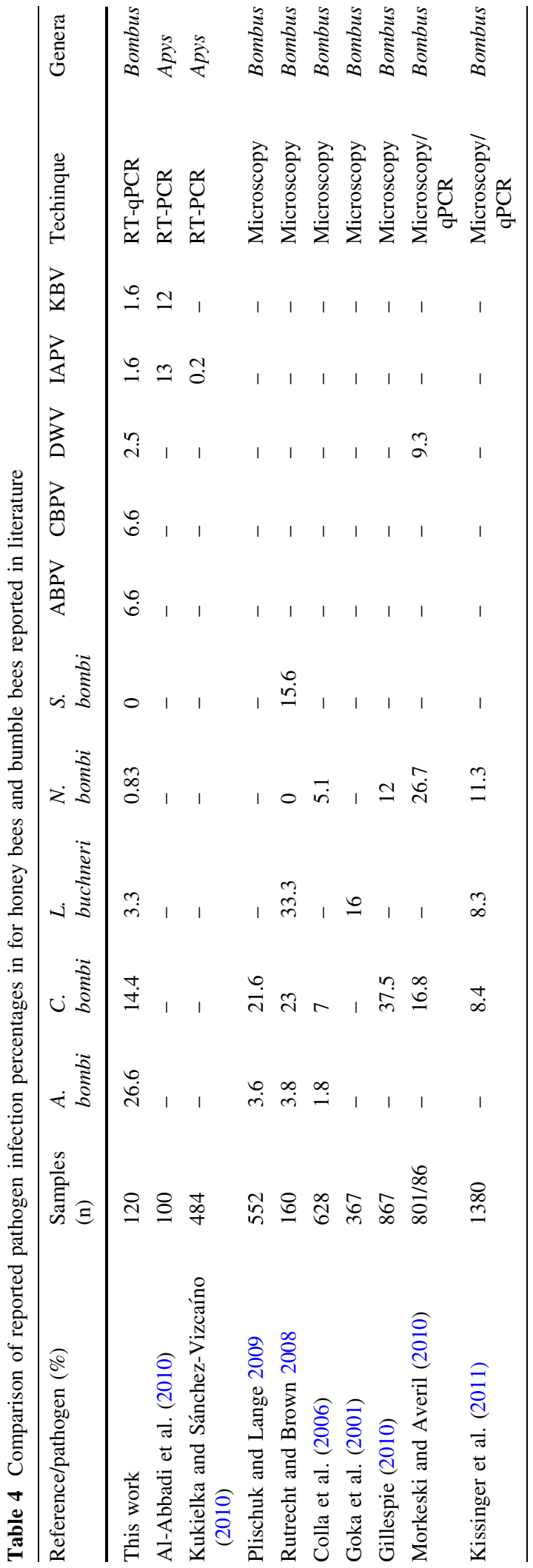

higher virulence in captivity. (2) Managed bumble bees may cause native pathogens to increase in prevalence, which could cause an epizootic in wild bumble bees. (3) There are concerns about genetic pollution. For example, recent research has found that B. ephippiatus is potentially comprised of three distinct species. Managed B. ephippiatus could breed with closely related wild species (Duennes et al. 2012b). (4). Nonnative commercial bumble bee species may establish in the wild and compete with native bumble bee species for food sources or nesting areas.

The centralized production of bumble bee colonies has clear advantages and disadvantages. The economic benefit of using these organisms in agricultural practices cannot be denied. On the other hand there is the latent risk that the transportation of infected bumble bees may transmit pathogens to other commercially important species, such as honey bees or other wild hymenopterans. As it has been demonstrated that greenhouse bumble bees transmit these viruses and eukaryotic pathogens to other hymenopteran species, such as Apis mellifera and vice versa (Graystock et al. 2013; Fürst et al. 2014).

Rigorous policy and routine pathogen monitoring should be implemented in a global scale (Meeus et al. 2011; Fürst et al. 2014). As it has been done in parts of Europe, where bumble bees producers must rigorously screen their production in order to maintain their import license (Murray et al. 2013; Graystock et al. 2013). Japan also requires that farms that use commercially reared bumble bees must also screen them routinely to break any possible transmission route (Goka 2010b). In conclusion, the routine pathogen screening using molecular technologies should become governmental policy and must be adopted by commercial bumble bee producers as soon as possible to avoid environmental dispersal of hymenopteran emerging infectious diseases, to maintain the sustainable production of bumble bees and the natural pollination services that different bumble bees species provide worldwide.

Acknowledgments We thank René Hernández Vargas for technical support, Santiago Becerra for oligonucleotide synthesis and Jorge Yañez for DNA sequencing. This study was supported by funds from DGAPA/UNAM IN203611 and DGAPA/UNAM IN204214 and CONACyT grant 131685. We also thank CONACyT for scholarship 167325, the UNAM, the Programa de Doctorado en Ciencias Biomédicas and Dr. Pablo Vinuesa for academic training. 
Open Access This article is distributed under the terms of the Creative Commons Attribution License which permits any use, distribution, and reproduction in any medium, provided the original author(s) and the source are credited.

\section{References}

Al-Abbadi AA, Hassawi DS, Abu-Mallouh SA, Al-mazra MS (2010) Novel detection of Israel acute paralysis virus and Kashmir bee virus from honeybees Apis mellifera L. (Hymenoptera: Apidae) of Jordan using reverse transcriptase PCR technique. Appl Entomol Zool 45:183-190

Arbetman MP, Meeus I, Morales CL, Aizen M, Smagghe G (2012) Alien parasite hitchhikes to Patagonia on invasive bumblebee. Biol Invasions 15:489-494

Bailey L, Gibbs AJ, Woods RD (1963) Two viruses from adult honey bees (Apies mellifera L.). Virology 21:390-395

Berényi O, Bakonyi T, Derakhshifar I, Köglberger H, Topolska G, Ritter W, Pechhacker H, Nowotny N (2007) Phylogenetic analysis of deformed wing virus genotypes from diverse geographic origins indicates recent global distribution of the virus. Appl Environ Microbiol 73:3>605-3611

Blanchard P, Schurr F, Celle O, Cougoule N, Drajnudel P, Thiéry R, Faucon JP, Ribière M (2008) First detection of Israeli acute paralysis virus (IAPV) in France, a dicistrovirus affecting honeybees (Apis mellifera). J Invertebr Pathol 99:348-350

Brown MJF (2011) The trouble with bumblebees. Nature 469:169-170

Brown MJF, Loosli R, Schmid-Hempel P (2000) Conditiondependent expression of virulence in a trypanosome infecting bumblebees. Oikos 91:421-427

Brown MJF, Schmid-Hempel R, Schmid-Hempel P (2003) Strong context-dependent virulence in a host-parasite system: reconciling genetic evidence with theory. J Anim Ecol 72:994-1002

Cameron SA, Lozier JD, Strange JP, Koch JP, Cordes N, Solter LF (2010) Patterns of widespread decline in North American bumble bees. PNAS 108:662-667

Celle O, Blanchard P, Olivier V, Schurr F, Cougoule N, Faucon JP, Ribière M (2008) Detection of Chronic bee paralysis virus (CBPV) genome and its replicative RNA form in various hosts and possible ways of spread. Virus Res 133:280-284

Colla SR, Otterstatter MC, Gegear RJ, Thomson JD (2006) Plight of the bumble bee: pathogen spillover from commercial to wild populations. Biol Conserv 129:461-467

Cox-Foster DL, Conlan S, Holmes EC, Palacios G, Evans JD, et al. (2007) A metagenomic survey of microbes in honey bee colony collapse disorder. Science (80-) 318:283-287

De Miranda JR, Drebot M, Tyler S, Shen M, Cameron CE, Stoltz DB, Camazine SM (2004) Complete nucleotide sequence of Kashmir bee virus and comparison with acute bee paralysis virus. J Gen Virol 85:2263-2270

Duennes MA, Lozier JD, Hines HM, Cameron SA (2012a) Geographical patterns of genetic divergence in the widespread Mesoamerican bumble bee Bombus ephippiatus (Hymenoptera: Apidae). Mol Phylogenet Evol 64:219-231
Duennes MA, Lozier JD, Hines HM, Cameron SA (2012b) Molecular phylogenetics and evolution geographical patterns of genetic divergence in the widespread Mesoamerican bumble bee Bombus ephippiatus (Hymenoptera: Apidae). Mol Phylogenet Evol 64:219-231

Fürst MA, McMahon DP, Osborne JL, Paxton RJ, Brown MJF (2014) Disease associations between honeybees and bumblebees as a threat to wild pollinators. Nature 506: 364-366

Gallai N, Salles J-M, Settele J, Vaissiére BE (2009) Economic valuation of the vulnerability of world agriculture confronted with pollinator decline. Ecol Econ 68:810-821

Gillespie S (2010) Factors affecting parasite prevalence among wild bumblebees. Ecol Entomol 35:737-747

Goka K (2010a) Introduction to the Special Feature for Ecological Risk Assessment of Introduced Bumblebees: status of the European bumblebee, Bombus terrestris, in Japan as a beneficial pollinator and an invasive alien species. Appl Entomol Zool 45:1-6

Goka K (2010b) Biosecurity measures to prevent the incursion of invasive alien species into Japan and to mitigate their impact The Invasive Alien Species Act in Japan. Rev Sci Tech Off Int Epiz 29:299-310

Goka K, Okabe K, Yoneda M, Niwa S (2001) Bumblebee commercialization will cause worldwide migration of parasitic mites. Mol Ecol 10:2095-2099

Govan VA, Leat N, Allsopp M, Davison S (2000) Analysis of the complete genome sequence of acute bee paralysis virus shows that it belongs to the novel group of insect-infecting RNA viruses. Virology 277:457-463

Graystock P, Yates K, Evison SEF, et al (2013) The Trojan hives: pollinator pathogens, imported and distributed in bumblebee colonies. J Appl Ecol 1207-1215

Graystock P, Goulson D, Hughes W. (2014) The relationship between managed bees and the prevalence of parasites in bumblebees. PeerJ 2:e522. doi:10.7717/peerj.522

Kearns CA, Thomson JD (2001) The natural history of bumblebees: a sourcebook for investigation. University Press of Colorado, Colorado

Kissinger CN, Cameron SA, Thorp RW, White B, Solter L, Hill G (2011) Survey of bumble bee (Bombus) pathogens and parasites in Illinois and selected areas of northern California and southern Oregon. J Invertebr Pathol 107:220-224

Kondo NI, Yamanaka D, Kanbe Y, Kawate YK, Yoneda M, Tsuchida K, Goka K (2009) Reproductive disturbance of Japanese bumblebees by the introduced European bumblebee Bombus terrestris. Naturwissenschaften 96:467-475

Kukielka D, Sánchez-Vizcaíno JM (2010) First detection of Israeli Acute Paralysis Virus (IAPV) in Spanish honeybees. Spanish J Agric Res 8:308-311

Lanzi G, De Miranda JR, Boniotti MB, Cameron C, Lavazza A, Capucci L, Camazine SM, Rossi C (2006) Molecular and Biological Characterization of Deformed Wing Virus of Honeybees (Apis mellifera L.). J Virol 80:4998-5009

Maharramov J, Meeus I, Maebe K et al (2013) Genetic variability of the neogregarine Apicystis bombi, an etiological agent of an emergent bumblebee disease. PLoS ONE 8:6-13

Maori E, Lavi S, Mozes-Koch R et al (2007) Isolation and characterization of Israeli acute paralysis virus, a 
dicistrovirus affecting honeybees in Israel: evidence for diversity due to intra- and inter-species recombination. J Gen Virol 88:3428-3438

Meeus I, de Graaf DC, Jans K, Smagghe G (2010a) Multiplex PCR detection of slowly-evolving trypanosomatids and neogregarines in bumblebees using broad-range primers. J Appl Microbiol 109:107-115

Meeus I, Smagghe G, Siede R, Jans K, de Graaf GC (2010b) Multiplex RT-PCR with broad-range primers and an exogenous internal amplification control for the detection of honeybee viruses in bumblebees. $\mathrm{J}$ Invertebr Pathol 105:200-203

Meeus I, Brown MJF, De Graaf DC, Smagghe G (2011) Effects of invasive parasites on bumble bee declines. Conserv Biol 25:662-671

Morkeski A, Averil 1AL (2010) Wild bee status and evidence for pathogen spillover with honey bees. Am Bee J 150(11): 1049-1052

Murray TE, Coffey MF, Kehoe E, Horgan FG (2013) Pathogen prevalence in commercially reared bumble bees and evidence of spillover in conspecific populations. Biol Conserv 159:269-276

Ollerton J, Winfree R, Tarrant S (2011) How many flowering plants are pollinated by animals? Oikos 120:321-326

Otterstatter MC, Thomson JD (2008) Does pathogen spillover from commercially reared bumble bees threaten wild pollinators ? PLoS ONE 3:1-9

Pitts-Singer T, James R (2008) Do weather conditions correlate with findings in failed, provision-filled nest cells of Megachile rotundata (Hymenoptera: Megachilidae) in western North America? J Econ Entomolo 101:674-685

Plischuk S, Lange CE (2009) Invasive Bombus terrestris (Hymenoptera: Apidae) parasitized by a flagellate (Euglenozoa: Kinetoplastea) and a neogregarine (Apicomplexa: Neogregarinorida). J Invertebr Pathol 102:263-265

Rutrecht ST, Brown MJF (2008) The life-history impact and implications of multiple parasites for bumble bee queens. Int J Parasitol 38:799-808

Shipp JL, Whitfield GH, Papadopolus AP (1994) Effectiveness of the bumble bee, Bombus impatiens Cr. (Hymenoptera: Apidae), as a pollinator of green house sweet pepper. Sci Hortic (Amsterdam) 57:29-39
Singh R, Levitt AL, Rajotte EG et al (2010) RNA viruses in hymenopteran pollinators: evidence of inter-taxa virus transmission via pollen and potential impact on non-Apis hymenopteran species. PLoS ONE 5:1-16

Stubbs CS, Drummond FA (2001) Bombus impatiens (Hymenoptera: Apidae): an alternative to Apis mellifera (Hymenoptera: Apidae) for lowbush blueberry pollination. J Econ Entomol 94:609-616

Tay WT, O’Mahony EM, Paxton RJ (2005) Complete rRNA gene sequences reveal that the microsporidium Nosema bombi infects diverse bumblebee (Bombus spp.) hosts and contains multiple polymorphic sites. J Eukaryot Microbiol 52:505-513

Velthius HW, Van Doorn A (2006) A century of advances in bumblebee domestication and the economic and environmental aspects of its commercialization for pollination. Apidologie 37:421-451

Watanabe ME (2006) Colony collapse disorder: many suspects, no smoking gun. Bioscience 58:384-388

Whitehorn PR, Tinsley MC, Brown MJF, Goulson D (2013) Investigating the impact of deploying commercial Bombus terrestris for crop pollination on pathogen dynamics in wild bumble bees. J Apic Res 52(3):149-157

Whittington RJ, Winston ML (2004) Comparison and examination of Bombus occidentalis and Bombus impatiens (Hymenoptera: Apidae) in tomato greenhouses. J Econ Entomolo 97:1384-1389

Yoneda MY, Uruta HF, Suchida KT, Kabe KO, Oka KG (2008) Commercial colonies of Bombus terrestris (Hymenopter: Apidae) are reservoirs of the tracheal mite Locustacarus buchneri (Acari: Podapolipidae). Appl Entomol Zool 43:73-76

Yue C, Genersch E (2005) RT-PCR analysis of Deformed wing virus in honeybees (Apis mellifera) and mites (Varroa destructor). J Gen Virol 86:3419-3424

Yukl SA, Boritz E, Busch M et al (2013) Challenges in detecting HIV persistence during potentially curative interventions: a study of the Berlin patient. PLoS Pathog 9:1-13 